\title{
Research on Lemon Industry Competitiveness Based on Porter Diamond Model
}

\author{
Minxiang Yue ${ }^{1, *}$ and Zhengyong $\mathrm{Cao}^{2}$ \\ ${ }^{1}$ College of Economics, Sichuan Agricultural University, Chengdu, Sichuan, China \\ ${ }^{2}$ College of Economics, Sichuan Agricultural University, Chengdu, Sichuan, China \\ *Corresponding author E-mail: 1447425489@qq.com
}

\begin{abstract}
Improving the agricultural industry competitiveness is the leading direction of high-quality agricultural development in the future. Therefor it is of great significance to research to how to improve the industrial competitiveness and promote the high-quality development of lemon industry in Chengdu-Chongqing area. Porter diamond model is selected to explore the current situation of lemon industry competitiveness from the aspects of factor conditions, demand status, related and supporting industries, industry development strategy, government role, opportunities. lemon industry has strong competitiveness. This region has unique location conditions, broad market prospects, strong government support, detailed development strategies and diverse development opportunities. However there are still many shortcomings and deficiencies, such as no cross regional big data platform. In addition, it is faces the problems of insufficient labor force, insufficient support for relevant industries and uncoordinated among regions. Therefore, the government should establish a cross regional big data analysis platform, cultivate labor talents and strengthen regional communication and cooperation.
\end{abstract}

Keywords: High-quality development, Industrial Competitiveness, Porter Diamond Model

\section{INTRODUCTION}

In 2016, the 13th five year plan for the development of national agricultural informatization made a clear plan for the work of agricultural, including taking agricultural modernization as the task, taking smart agriculture as the goal, and taking big data prediction as the basis to establish an agricultural service system. At present, agricultural development has entered the era of big data, and the role of big data analysis technology to the high-quality development of agricultural industry is becoming increasingly prominent.

In recent years, lemon industry has developed rapidly. China is the third largest lemon (including lime) producer in the world, with an area of 100.4 hectares, accounting for $9.2 \%$ of the world. The output is 2.317 million tons, accounting for $13.4 \%$ of the world. Anyue of Sichuan, Tongnan of Chongqing and Dehong of Yunnan are the three major lemon producing areas in China. Chengdu-Chongqing region is the largest lemon production area in China, accounting for more than $90 \%$ of the output.

For the high-quality development of agriculture, competitiveness is the fundamental reason for its existence and the driving force for its development ${ }^{[1]}$. Under the background of high-quality development, industrial competitiveness is an important factor affecting the development of agricultural high-quality. It is worth exploring to how to improve the competitiveness of lemon industry based on the high-quality development of agriculture. Therefore, this paper analyzes the current situation of lemon industry competitiveness by using Porter diamond model, and discusses how to improve the competitiveness of lemon industry, so as to promote the high-quality development of lemon industry.

\section{ANALYZE THE CURRENT SITUATION OF LEMON INDUSTRY COMPETITIVENESS BASED ON PORTER DIAMOND MODEL}

\subsection{Porter's Diamond Model}

In 1990, Professor Michael E. Porter of Harvard University put forward the "Diamond Model". The theory includes production factors, demand conditions, performance of related industries and supporting industries, enterprise strategy, structure and competitors. 
In addition, there are two variables including "opportunity" and "government". Porter diamond model is widely used in the analysis of industrial competitiveness of manufacturing industry, conversely it is seldom used in agriculture ${ }^{[2]}$. This paper attempts to use diamond theory to analyze the core level of high-quality development of lemon industry in Chengdu-Chongqing area, that is the current situation of industrial competitiveness. We adjust the Porter Model. It is shown in Figure 1.

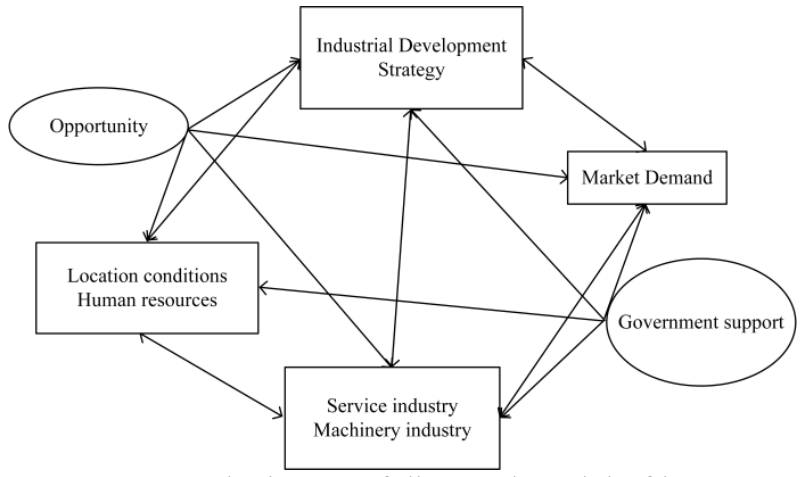

Figure 1. The image of diamond model of lemon industry competitiveness

\subsection{Analysis of Lemon Industry Competitiveness based on Diamond Model}

Firstly, production factors include primary factors such as location conditions and advanced factors of human resources. (1) Location conditions. Chengdu-Chongqing area refers to the area between Chengdu and Chongqing, with an area of about 200000 square kilometers and a population of 87.24 million, accounting for $6.6 \%$ and $35 \%$ of Southwest China respectively. It is one of the important urban belts inChina. Because of its unique natural conditions and long planting history, Chengdu-Chongqing area hasbecame the largest lemon producing areas in China. (2) Human resources. Anyue has set up a lemon academician and expert workstation. Tongnan has lemon detoxification center, lemon technology innovation center, postdoctoral research station, lemon technology expert courtyard, and other science and technology research centers. Sichuan and Chongqing sign the talent exchange alliance agreement of colleges and universities, which is conducive to the introduction and cultivation of agricultural big data talents. But for lemon farmers, most of them are the old and women, and there is a lack of young labor force.

Secondly, market demand. Lemon is mainly exp-orted. The fresh fruits and processed products of A-nyue lemon are exported to more than 30 countries and regions, and the foreign market is dominant. With the improvement of people's living standard and the change of consumption concept, the consumption of lemon and its processed products is increasing, which greatly promotes the lemon sales in the neighboring areas of Chengdu-Chongqing, and the domestic market is expanding gradually.

Thirdly, related and supporting industries. Although all regions gradually attach importance to the development of local new business entities, there is no unified lemon technical service team, no unified new business entity responsible for lemon related matters, and no systematic and perfect lemon supporting service industry in the region. The adjacent area of Chengdu and Chongqing is located in the southwest. The development level of mechanization industry needs to be improved. It can only provide low-level and miniaturized machinery and equipment for lemon industry. Lemon planting is still dominated by manual labor.

Fourthly, industrial development strategy. Tongnan has built some national demonstration zones, including a national demonstration zone for quality and safety of exported food and agricultural products, a national modern agricultural (lemon) Industrial Park, a comprehensive and standardized demonstration zone for lemon production, and a lemon detoxification and seedling breeding center. Tongnan also accelerated the construction of a modern lemon industrial cluster with production factors. Anyue has built a national modern agricultural industrial park, and built "four bases" for the breeding, standardized planting, processing and cultural and creative tourism of lemon.

Fifthly, government support. Government support is an important factor to improve the competitiveness of cross regional industries. Local governments attach great importance to the coordinated development of lemon industry in the region, and have issued a series of measures to improve the competitiveness of lemon industry. Table 1 shows the policies issued by the state and Chengdu-Chongqing region from 2015 to 2020 to promote the development of lemon industry. Because of the limited length of the article, representative documents are selected every year. It shows that in the past five years, the government's policies related to the development of lemon industry cover lemon land, insurance and brand, but do not involve lemon data collection, analysis and protection system. The government lacks consciousness of the big data development, and the establishment of data thinking needs to be strengthened. 
Table 1. Lemon industry policies of the state and Chengdu-Chongqing region

\begin{tabular}{|c|c|c|c|c|}
\hline Time & The name of the policy & $\begin{array}{l}\text { Policy issuing } \\
\text { Level }\end{array}$ & $\begin{array}{l}\text { Policy issuing } \\
\text { department }\end{array}$ & Key content \\
\hline \multirow[t]{2}{*}{2015} & $\begin{array}{c}\text { Promotion plan for supporting the } \\
\text { development of lemon industry in } \\
\text { Anyue }\end{array}$ & Ziyang & $\begin{array}{c}\text { People's } \\
\text { Government }\end{array}$ & $\begin{array}{l}\text { Investment pull, project } \\
\text { driven, innovation driven, } \\
\text { planning driven }\end{array}$ \\
\hline & $\begin{array}{c}\text { Notice on further improving the } \\
\text { management of facility agricultural land } \\
\text { and supporting the healthy } \\
\text { development of facility agriculture }\end{array}$ & $\begin{array}{l}\text { TongNan } \\
\text { County }\end{array}$ & $\begin{array}{c}\text { People's } \\
\text { Government }\end{array}$ & $\begin{array}{c}\text { The development land of } \\
\text { lemon industry base is } \\
\text { guaranteed }\end{array}$ \\
\hline \multirow[t]{2}{*}{2016} & $\begin{array}{l}\text { Promoting the structural reform of } \\
\text { agricultural supply side and accelerating } \\
\text { the action plan of agricultural innovation } \\
\text { and green development in Sichuan }\end{array}$ & $\begin{array}{l}\text { Sichuan } \\
\text { Province }\end{array}$ & $\begin{array}{l}\text { General Office of } \\
\text { the people's } \\
\text { Government }\end{array}$ & $\begin{array}{l}\text { Building lemon regional } \\
\text { brand }\end{array}$ \\
\hline & $\begin{array}{l}\text { Notice on pilot work of income } \\
\text { insurance for vegetables and lemons }\end{array}$ & $\begin{array}{l}\text { TongNan } \\
\text { County }\end{array}$ & $\begin{array}{l}\text { Agricultural and } \\
\text { Rural Committee }\end{array}$ & Lemon income insurance \\
\hline 2017 & $\begin{array}{l}\text { Notice on printing and distributing the } \\
\text { implementation plan of lemon } \\
\text { characteristic agricultural insurance in } \\
\text { Anju District of Suining City }\end{array}$ & $\begin{array}{l}\text { Anju District of } \\
\text { Suining City }\end{array}$ & $\begin{array}{l}\text { Office of the } \\
\text { people's } \\
\text { Government }\end{array}$ & Lemon insurance \\
\hline 2018 & $\begin{array}{l}\text { Suggestions on accelerating the } \\
\text { development of lemon industry }\end{array}$ & $\begin{array}{l}\text { TongNan } \\
\text { County }\end{array}$ & $\begin{array}{l}\text { Office of the } \\
\text { people's } \\
\text { Government }\end{array}$ & $\begin{array}{l}\text { Promote the development } \\
\text { of lemon }\end{array}$ \\
\hline 2020 & $\begin{array}{l}\text { Announcement on the construction list } \\
\text { of advantageous and characteristic } \\
\text { industrial clusters in } 2020\end{array}$ & Country & $\begin{array}{c}\text { Ministry of } \\
\text { agriculture and } \\
\text { rural affairs } \\
\text { Ministry of } \\
\text { Finance }\end{array}$ & $\begin{array}{l}\text { Building lemon industry } \\
\text { cluster in Chongqing }\end{array}$ \\
\hline & $\begin{array}{c}\text { Strategic cooperation framework } \\
\text { agreement on the construction of } \\
\text { Chengdu-Chongqing modern efficient } \\
\text { characteristic agricultural belt }\end{array}$ & $\begin{array}{l}\text { Chengdu } \\
\text { Chongqing }\end{array}$ & $\begin{array}{c}\text { Chongqing } \\
\text { Agricultural and } \\
\text { Rural Committee, } \\
\text { Sichuan Provincial } \\
\text { Department of } \\
\text { Agriculture and } \\
\text { Rural Affairs }\end{array}$ & $\begin{array}{l}\text { Boosting the development } \\
\text { of industrial clusters in the } \\
\text { world lemon }\end{array}$ \\
\hline & $\begin{array}{c}\text { "10 + 3" agricultural development } \\
\text { system }\end{array}$ & $\begin{array}{l}\text { Sichuan } \\
\text { Province }\end{array}$ & $\begin{array}{l}\text { Department of } \\
\text { Agriculture and } \\
\text { Rural Affairs }\end{array}$ & $\begin{array}{l}\text { Building lemon National } \\
\text { Modern Industrial Park }\end{array}$ \\
\hline
\end{tabular}

Note: The information comes from the official websites of governments at all levels by author's manual arrangement. Due to the timeliness of the publication of the documents, the relevant documents for 2019 were not found.

Sixthly, opportunities. In 2020, the construction strategy of Chengdu-Chongqing double city economic circle was put forward, in the same year, Sichuan proposed the construction of "10 + 3" characteristic agricultural industrial system, which brought unprecedented development opportunities for the lemon industry. The cooperation between the two places has fully promoted the exchange of lemon technical talents 
and the flow of funds, and provided a solid foundation for the establishment of big data platform.

\section{CONCLUSION}

Based on Porter diamond model to analyze the competitiveness of Chengdu-Chongqing lemon industry, we can draw the following conclusions. This paper finds that lemon industry has strong competitiveness. This region has unique location conditions, broad market prospects, strong government support, detailed development strategies and diverse development opportunities. However there are still many shortcomings and deficiencies, such as no cross regional big data platform, which greatly restricts the high-quality development of lemon industrial competitiveness. Besides it is faces the problems of insufficient labor force, insufficient support for relevant industries and uncoordinated among regions.

In order to make up for the lack of competitiveness of lemon industry, the following suggestions are put forward.

First of all, the government should develop the big data management and control mode, and establish the big data analysis platform of lemon industry across regions $^{[3]}$. Chengdu-Chongqing region should give full play to the role of the government at the leadership level and break the administrative barriers. It is helpful for them to build a "lemon high-quality development big data platform", containing three-level lemon data platform. Basic data platform refers to the establishment of basic agricultural big data monitoring system in the field, which is responsible for field data collection and monitoring, including crop growth monitoring and land nutrient value monitoring. Local data platform refers to the establishment of local lemon industry data platform in Anyue and other counties, which is responsible for the analysis and collation of lemon processing and sales data. Comprehensive data platform refers to the establishment of lemon industry big data comprehensive platform in Chengdu-Chongqing area, which is responsible for the data monitoring of the whole region. It is mainly in favor of lemon processing, sales and other data collection, as well as disaster warning and land planning. The ultimate goal is to establish a comprehensive data management application system. This is good to the formation of a closely connected and closely linked lemon industry big data platform pattern, and provides data support for the government to formulate sound lemon industry development policies.

Then, we should develop the Agricultural Internet of things and the smart lemon industry by using advanced big data application system. At the same time, we should use the tracing technology of agricultural products to accurately grasp the consumption demand of lemon products ${ }^{[4]}$. Besides we should cultivate big data analysis talents of lemon industry and introduce agricultural economic management information system, in order to change the sales plan of products in time and accurately meet the needs of consumers.

Finally, we should cultivate talents of lemon industry and introduce agricultural economic management information system ${ }^{[5]}$. In addition, we should strengthen the development of related industries and promote cross regional communication and cooperation.

\section{REFERENCES}

[1] Han C F.2018. Vigorously promote the quality and green development of agriculture and accelerate the realization of high-quality agricultural development [N]. Farmers Daily, February 27, 2018 (001)

[2] Tsai, P. H., Chen, C. J., \& Yang, H. C. (2021) Using porter's diamond model to assess the competitiveness of taiwan's solar photovoltaic industry. SAGE Open, 11.

[3] Gang-Hoon, Kim, Silvana, Trimi, Ji-Hyong, \& Chung. (2014) Big-data applications in the government sector. Communications of the ACM, 57(3), pp.78-85.

[4] Tan Zhixin, Zhang Zhaoxin. Thoughts and suggestions on improving the competitiveness of China's agricultural industry system[J].Rural Finance Research,2021(06):52-58.

[5] Cao Haixia, Han Donge. Research on industrial regulation and enterprise incentive in resource-based regions [J]. Economic Issues, 2015 (10): 118-123. 